\title{
Tamarack Tales
}

\section{by KERRY WOOD, Red Deer, Alberta}

Fishing first took us to the Tamarack Swamp, trying to catch walleyes and pike on spinners and homemade wooden plugs. There was a sizeable backwater where the swamp creek drained into the river, and there we cast our lures and hoped for luck.

Sometimes the fish wouldn't bite. To get relief from the glare of the afternoon sun on that exposed river bank, we'd put our rods aside and walk back into the shady swamp where the lacy-leafed tamaracks thrived. The only evergreen to shed its needles, the tamarack was enough of a rarity in our district to make us narvel at its graceful shape and pale green needle color.

Once in the swamp, we'd look around for flowers. Some rare blooms were found there every summer. Dainty Fly-speck Orchis and the intriguing white pouches of Ladyslippers, a dwarf member of the rose family called Arctic Raspberry, and the tiny primroses. Labrador Tea was abundant, a fleshy-leafed plant from which we brewed a pleasant drink as the Indians had done for centuries past. We were always delighted to find Early Blue Violets, the largest and loveliest members of that fine family in our district. Bog Wintergreen hasn't too pleasant a sound as a name, but we thrilled to find the delicate flowers of this marshland beauty. On the higher knolls near the swamp grew a scented carpet of fairy-like bells called Twin-Flowers.

Berries were always plentiful. The dark crimson of woodland strawberries, lacking the sunny sweetness of meadow fruits but most acceptable as a wild confection on the warmer days of summer. We could never find enough Dewberries to provide a feast, each of the raspberry shaped clusters tasting like sweetened spring water. The tart gooseberries thrived among the tangle of shrubs at the base of the hill, and there you might also find wild currants of both black and red varieties. The puckery chokecherries and the sweet saskatoons ripened on the slopes above the swamp. One shade-loving berry we always viewed with suspicion, its glossy black fruits enclosed in bright red bracets that seemed to shout a warning of poison. Later on, we learned that these Black Twinberries were not dangerous, but merely unpalatable.

Amid the conifer marsh lived many birds. Wilson's Snipe whickered above the swamp at evening and on cloudy days; the ascending pulse of their whickering produced by the bird's tailfeathers held at a certain angle as the snipe speeds high above the swamp. Killdeer plovers were there, Solitary Sandpipers near a creeklet, and you often flushed Lecontes Sparrows from the slough grass. The Veery sang from the dark ravine, a glorious thrush music that might be satisfactorily reproduced by an orchestra of flutes. Another bird found among the evergreen branches was the Ruby-Crowned Kinglet, as tiny as a wren but with a rollicking song that could fill the whole woodland with joyous melody. At evening the White-throat's benediction rang out, clear as a silver bugle sounding in the flower-scented dusk. Then, as night deepened, came the booming hoot of Great Horned Owls.

From the hill above the marsh there was a long sweeping view of river scenery, the stream framed with poplars and spruces as it wound through rich farmlands. And at the end of the ridge from which we enjoyed this scene there was an abrupt little knoll that always fascinated us. The surrounding terrain was flat hilltop, out of which rose the rounded knoll that always looked somewhat artificial there. Finally, a couple of us fetched a shovel along on one of our fishing jaunts and we started to dig into that knoll. But we hastily replaced the earth when we discovered that it was an Indian graveyard.

An old-timer explained the reason for the grave's location on the edge of the hill. The chieftains of the tribe that once made this land their home were always buried on promtheir final journey to the Spirit-land inent hilltops that commanded a view 
of water to the west. The Spirit Guide was reputed to come in a ghostly white canoe on the night of the full moon, down that water from the Land of the Setting Sun. The Guide paddled down the rivers to the hills where the chiefs were sleeping, gathering the souls of the noble leaders and taking them on beyond the Sunset.

This was our Tamarack Swamp, known to only a few fishermen. It was spoiled for a while, as the farmer attempted to drain off the marsh and make it a pasture for cattle. The wasteland resisted his efforts, and did not drain dry. After he'd lost a couple head of cattle in the treacherous bogland where they tried to graze, the farmer reconsidered his plans and left the Swamp in its original wild state. He cuts a tamarack post or two in the wintertime when it is safe to penetrate the frozen depths of the tangles, but the rest of the year the Swamp is a wilderness where birds and animals and flowers thrive untouched. And at the end of the high hill, the Indian grave can still be seen. You may go there on a moonlit night and stare westward along the shimmering river, watching for the ghostly white canoe that never comes.

\section{EDITOR'S NOTE:}

\section{"WILD WINTER"}

Those who have read Kerry Wood's "The Sanctuary," will be pleased to know that his newest book, "Wild Winter," is just off the pruss. Like his other writings, this book reflects Mr. Wood's keen love of nature and his intimate knowledge of forest lore and of the plants and animals which abound near his home at Red Deer, Alberta.

This is a book which will be eagerly read by teen age boys who revel in adventure and in the hidden mysteries of nature which are revealed only to those who live with nature.

It is the story of a struggle, hardships and triumphs of a boy, who with scarcely any provisions, lives alone in the forest during the long cold winter, existing only on the meagre food that can be found about him.
The publishers are Houghton Mifflin Company, 2 Park Street, Boston 7. There is no doubt but that the book may be obtained by any of our larger book stores. The price is $\$ 2.25$.

\section{Help Wanted}

Mrs. Harold Bray, McLean, Sask.

When we pause to consider the concern we, as nature lovers, have for our feathered friends, especially during unseasonable storms, what appreciation do we get from the general public and farming folk (there are exceptions of course) in view of the fact that these very birds we have been feeding are very beneficial in checking the myriads of insects which could destroy much of their crop, particularly green aphids on oats, which are much relished by numerous small birds, such as Yellow Warblers, Chickadees, etc. Also as important are those birds who flock over our fields in spring and fall in search of weed seeds. Then there are those much despised birds, the crows, doing away with many grasshoppers during a plague year, and lastly, the hawks and owls who destroy many mice from our grain fields.

The farmer who does away with every vestige of tree and bush along his fence has no appreciation of the beneficial friends who might nest there. I hope that all will show their appreciation by protecting their nesting places, particularly old hollow trees for the woodpeckers and all birds who use such places. These trees should be left standing unless they are in such rotten condition that the wind could topple them.

\section{JOHN BURROUGHS}

\section{PRECIOUS RESOURCES OF LIFE}

"If I were to name the three most precious resources of life, I would say books, friends and nature; and the greatest of these is nature.

The born naturalist is one of the most lucky men in the world. Winter or summer, rain or shine, at home or abroad, walking or riding, his pleasures are always near at hand. The great book of nature is open before him and he has only to turn its leaves." 